\title{
Legal Basis of China's Claim over the Huangyan Island
}

\author{
Ran Guo*
}

Official Announcements of China and the Philippines have clarified their claims over the Huangyan Island, which has compartmentalized its history into three periods. Period I: Before 1946. China had acquired its title by discovery of terra nullius, and consolidated into a full title with the historical consolidation process. The Philippines made no claims in this period; instead its laws confirmed the Island lies out of its territory. Period II: 1946-1997. The Philippine evidences are private in nature, or contradictory to its laws and governmental position, thus making its claims vulnerable. China had exercised an open and peaceful effective occupation over the Island with superior evidences. Period III: After 1997. According to the ICJ judgment, April 30, 1997 was tentatively determined the critical date. Since China acquired its territorial sovereignty over the Island before the critical date, the Philippines' acts cannot alter China's ownership of the Island.

\section{Keywords}

The Huangyan Island, Territorial Acquisition, Critical Date, Inter-temporal International Law

* Lecturer at East China Normal University, Shanghai, China. B.A. (Henan Normal Univ.), M.A. (Tianjin Foreign Studies Univ.), Ph.D. (Wuhan Univ.). This research was supported by the following research projects: "The Legal Dilemma and its Solution of China's Oil and Gas Exploitation in Nansha" (Project No. 2013BFX003) sponsored by the Shanghai Planning Office of Philosophy and Social Science and "The Interpretation of Historic Title and its Function in the Dispute over Nansha" (Project No. CLS, 2012, D231) sponsored by the Chinese Law Society. Much gratitude is extended to Professor Zewei Yang of Wuhan University for his advice. The author may be contacted at: rguo@fl.ecnu.edu.cn / Address: School of Foreign Languages, East China Normal University, Shanghai, China, 200062.

DOI: http://dx.doi.org/10.14330/jeail.2013.6.2.09 


\section{Introduction}

The Huangyan Island ${ }^{1}\left(15^{\circ} 07^{\prime} \mathrm{N}, 117^{\circ} 51>\mathrm{E}\right)$ lies in the southeast Zhongsha Islands, Sansha City, Hai'nan Province, China. It is about 160nm from Macclesfield Bank and approximately $130 \mathrm{~nm}$ from Luzon Island of the Philippines. ${ }^{2}$ As the only island above sea level during high tide in the Zhongsha Islands, the Island forms a triangleshaped chain of reefs, rocks and islets, some of which are $0.5 \mathrm{~m}$ to $3 \mathrm{~m}$ above water, such as South Rock $(1.8 \mathrm{~m})$ and North Rock $(1.5 \mathrm{~m}){ }^{3}$ encompassing a $15 \mathrm{~m}$ deep lagoon with a total area of $130 \mathrm{~km}^{2}$. China's sovereign jurisdiction over the island had never been challenged until April 30, 1997, when the Filipino navy drove an international amateur radio group away from the island and began to claim sovereignty over the Huangyan Island. ${ }^{4}$ Since then, the Filipino navy has repeatedly detained and even sunk Chinese fishing boats, arrested Chinese fishermen, and carried out socalled law enforcement activities on the Island. Meanwhile, the Philippine baseline law in $2009^{5}$ and initiation of the arbitral proceedings against China in 2013 have consistently escalated tension with China. ${ }^{6}$

The primary purpose of this research is to prove China's sovereign jurisdiction over the Huangyan Island from an international legal perspective. This article is composed of four parts including Introduction and Conclusion. Part two will compare their claims and narrow down the dispute. Part three will probe into their official claims through both the history of the Huangyan Island and the corresponding factual or evidences made by each party under international law and ICJ judgment. This is all investigated to reach a legally sound conclusion of the ownership of the Huangyan Island.

1 The Huangyan Island (simplified Chinese:黄岩岛; traditional Chinese: 黄岩島; pinyin: Huángyán Dăo) is also known as Scarborough Shoal or Scarborough Reef in English, Bajo de Masinloc or Panatag Shoal (Kulumpol ng Panatag in Filipino) by the Philippines.

2 Jinming Li, On the Sovereignty Ownership of Scarborough Reef on the Basis of History and International Law of the Sea, 4 China's Borderland History and Geography Studies 71-77 (2001).

3 See Introduction to the Huangyan Island, China Unanhai (available only in Chinese), available at http://www. unanhai.com/a/zhongshaqundao/2012/1212/1151.html (last visited on Sept. 2, 2013); ZHENHUA HAN, A COLLECTION OF Historical Documents on China's South China Sea 703 (1988).

$4 \quad$ Supra note 2.

5 The Philippine president Gloria Macapagal-Arroyo approved Republic Act No. 9522 to define the archipelagic baselines of the Philippines on Mar. 10, 2009.

6 The Philippines initiated the arbitral proceedings to acquire its sovereign rights and jurisdiction over part of the South China Sea, including the waters adjacent to the Huangyan Island, on Jan. 22, 2013, despite China's reservation to the dispute settlement procedures. 


\section{Claims of China and the Philippines}

\section{A. The Official Announcements}

During the Sino-Philippine stand-off in 2012, both Parties issued official announcements in order to clarify their claims over the Huangyan Island as well as their legal and factual foundations. They are: (1) "Some Basic Facts on China's Sovereignty over the Huangyan Island" ${ }^{7}$ by the Chinese Embassy in the Philippines; (2) "China's Sovereignty over the Huangyan Island has a Sound Legal Basis," published in the People's Daily (hereinafter Chinese Announcement); (3) "Philippine Position on Bajo de Masinloc and Waters within its Vicinity" by the Philippine Department of Foreign Affairs (hereinafter the Philippine Announcement).

\section{B. Focus of the Announcements}

The Philippine Announcement claims that the basis of the Philippine sovereignty and jurisdiction over the Island is not premised on the Treaty of Paris, or proximity, ${ }^{10}$ or the fact that it is within its 200nm Exclusive Economic Zone ("EEZ") or Continental Shelf ("CS") under the UN Convention on the Law of the Sea ("UNCLOS”). ${ }^{11}$ Based

7 See Embassy of the People's Republic of China in the Republic of the Philippines, Some Basic Facts on China's Sovereignty over the Huangyan Island, Apr. 13, 2012, available at http://ph.china-embassy.org/eng/xwfb/t922594.htm (last visited on Sept. 2, 2013).

8 Sheng Zhong, China's Sound Legal Basis for Its Territorial Sovereignty over the Huangyan Island (中国对黄岩岛的 领土主权拥有充分法理依据) (available only in Chinese), People's DaILy, May 9, 2012, at 3, available at http://paper. people.com.cn/rmrb/html/2012-05/09/nbs.D110000renmrb_03.htm (last visited on Sept. 21, 2013).

9 See Department of Foreign Affairs of the Republic of the Philippines, Philippine Position on Bajo de Masinloc and Waters within its Vicinity, Apr. 18, 2012, available at http://www.gov.ph/2012/04/18/philippine-position-on-bajo-demasinloc-and-the-waters-within-its-vicinity (last visited on Sept. 2, 2013).

10 Philippines once claimed the sovereignty of the Huangyan Island on the basis of proximity. See [Philippine] WorLD NEws, Feb. 3, 2000, at 2. See also Li, supra note 2. Obviously, the Spokesman's remark is against ICJ judgment: "The title of contiguity, understood as a basis of territorial sovereignty, has no foundation in international law." See Island of Palmas (Neth. v. U.S.), Award, 1928 Perm. Ct. Arb. (PCA) 869 (Apr. 4). Also, it is contrary to international practice. E.g., Australian Christmas Island, located $1400 \mathrm{~nm}$ northwest Australia but only 270nm south of Indonesia; Greek islands in the eastern Aegean Sea along the Turkish coast, such as Samos and Ikaria, Chios, Lesbos and Lemnos, with Samos island only $0.86 \mathrm{~nm}$ from Anatolia (Turkey); the British Channel Islands off the French coast of Normandy; and even some of the Philippine Sulu Archipelago islands, which are only $3 \mathrm{~nm}$ away from Borneo. There is no law that transfers the sovereignty of these islands to the coastal countries because their proximity.

11 The Philippines once claimed the sovereignty of the Huangyan Island on this basis of UNCLOS. The Philippine president Aquino said in January 2013 that: "Bajo de Masinloc under UNCLOS is part of our EEZ, which says 200 miles, and it is 120 miles." See A. Calica, Consensus sought on Phl move vs China, The Philippine Star, available at http://www.philstar.com/headlines/2013/01/27/901512/consensus-sought-phl-move-vs-china (last visited on Sept. 21, 2013). This has no international legal basis because it is a basic principle of the international maritime law that 200 
"[o]n other principles of public international law," however, "the Philippines has exercised both occupation and effective jurisdiction over Bajo de Masinloc since its independence," to which the Philippines has adduced historical evidence, such as designation, maps, flag-raising, military utilization, scientific studies, and legislation.

Conversely, the Chinese Announcement claims that its territorial sovereignty over the Huangyan Island is anchored on international laws on territorial acquisition such as first discovery and its continuous, peaceful, and effective occupation has consolidated the inchoate title to full sovereignty. China adduces evidence including historical records, designation, territorial jurisdiction, and a long history of development and exploitation of the Island. It further claimed that: "Until 1997, the Philippines has never disputed China's jurisdiction and development on the Huangyan Island, instead it repeatedly stated that the Island was outside the Philippine territory."

Both Announcements suggest whether China or the Philippines owns the Huangyan Island depends on which Party had its sovereignty in 1946, and which Party has exercised an effective occupation and jurisdiction over the Island since 1946.

\section{The Sovereignty of the Huangyan Island}

If comparing the Chinese Announcement with the Philippines,' two important dates would be highlighted as a starting point of the Philippines' claim of sovereignty over the Huangyan Island: One is July 4, 1946 - the Philippines' independence day, which is insisted by the Philippines; the other is April 30, 1997 which is insisted by China. For a comprehensive and evidence-based analysis of both claims, the history of the Huangyan Island shall be divided into three periods: (1) Period I: Before 1946; (2) Period II: 1946-1997; and (3) Period III: After 1997.

\section{A. The Ownership in Period I: Before 1946}

The Chinese Announcement claims that China has owned the Huangyan Island since ancient times based on the following evidence: the Island was first discovered and 
drawn into China's map in the Yuan Dynasty (1271-1368 AD); Chinese fishermen have been fishing in its waters since then; and in 1935, the Map Verification Committee of China declared sovereignty over 132 islands reefs and shoals, including this Island. Nonetheless, the Philippines, without any claims or evidence formed before 1946, just refuted the Chinese Announcement by insisting that historical claims, fishing activities or maps" "could not be a basis for acquiring a territory" and China's historical title has not satisfied the criteria of an "open, continuous, adverse" long usage that is "peaceful and acquiesced by other States."13 Two questions pending discussion are as follows:

\section{Can China Legally Acquire its Territorial Sovereignty over the Huangyan Island on the Basis of Discovery?}

Under international law the modes of territorial acquisition include discovery, occupation, conquest, prescription, cession and accretion. ${ }^{14}$ In particular, a State could acquire the territorial sovereignty over a terra nullius with discovery and symbolic occupation before the mid-eighteenth century. ${ }^{15}$ Therefore, the fact that China discovered the Huangyan Island and put it under its jurisdiction in the thirteenth century, with Chinese fishermen taking it as their fishing ground ever since, was enough for China to acquire its territorial sovereignty on the basis of inter-temporal international law.

The related international treaties and domestic laws of the Philippines have proved China's sovereignty over the Island, as well. First, the Philippine territory is strictly confined by the 'Treaty Limits' (Figure 1), which has been stipulated with accuracy by The Treaty of Paris (1898), ${ }^{16}$ The Treaty of Washington $(1900)^{17}$

12 The Philippine Announcement claims that "maps are not significant factors in the determination of international tribunals' determination of sovereignty." However, it tries to prove its sovereignty with two maps, which had been drawn by private individuals with inaccuracy and source yet to be proved. The Tribunal decided: "Only with the greatest caution can account be taken of maps in deciding a question of sovereignty," and only "official or semi-official maps ... would be of special interest." These maps are of little importance to the case. See Island of Palmas (Neth. v. U.S.), Award, 1928 Perm. Ct. Arb. (PCA) 852 (Apr. 4).

13 Supra note 9 (Philippine Announcement).

14 R. Jennings, The Acquisition of Territory in International Law 16-35 (1963).

15 See Island of Palmas (Neth. v. U.S.), Award, 1928 Perm. Ct. Arb. (PCA) 839 (Apr. 4). See also M. Shaw, International Law 425 (5th ed. 2003); J. Crawford, The Creation of States in International Law 173-185 (1979); and supra note 14.

16 Treaty of Peace between the United States and Spain (Dec. 10, 1898), available at http://avalon.law.yale.edu/19th century/sp1898.asp (last visited on Oct. 6, 2013).

17 Treaty between the Kingdom Spain and the United States of America for cession of outlying islands of the Philippines [1900], available at http://www.gov.ph/1900/11/07/the-philippine-claim-to-a-portion-of-north-borneo-treaty-betweenthe-kingdom-spain-and-the-united-states-of-america-for-cession-of-outlying-islands-of-the-philippines-1900 (last visited on Oct. 6, 2013). 
and The Treaty with Great Britain (1930). ${ }^{18}$ The map indicates that the west limit of the Philippines territory is $118^{\circ} \mathrm{E}$ meridian of longitude. The Huangyan Island is obviously outside the limit.

Figure 1: Treaty Limits of the Philippine Territory ${ }^{19}$

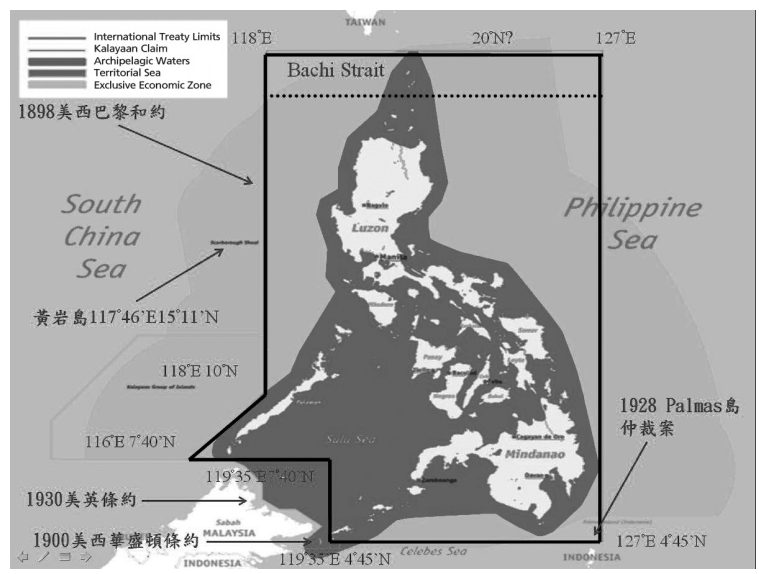

The Philippines not only extended no claim over the territory of the Huangyan Island in this period, but also excluded the Island from its territory with its domestic legislations including its 1935 Constitution. Although the Philippines resorts to the "catch-all clause" ${ }^{20}$ to break the "Treaty Limits, ${ }^{, 2}$ this has even been opposed by Philippine scholars, ${ }^{22}$ given the fact that, throughout the long history before 1997, and especially

18 Convention between the United States of America and Great Britain delimiting the boundary between the Philippine archipelago and the State of North Borneo [1930], available at http://www.gov.ph/1932/12/15/convention-betweenthe-united-states-of-america-and-great-britain-delimiting-the-boundary-between-the-philippine-archipelago-and-thestate-of-north-borneo-1930/ (last visited on Oct. 6, 2013).

19 The Treaty Limits were not intended to establish the Philippine territorial or sea boundaries. Instead, its geographical shorthand encloses all Philippine islands with coordinates, so as to separate the islands from those belonging to other States. Treaty of Peace between the United States and Spain (1898) ceded to the United States "the archipelago known as the Philippine Islands, and comprehending the islands lying within the following line" (Article III). See supra note 2. The United States, as one Party to the Paris Treaty, argues that the cession merely covered a transfer of the islands lying, and not the waters, within the lines. See J. Roach \& R. Smith, United States Responses to Excessive Maritime Claims 221 (1996).

20 It mean that its territory consists of the archipelago and "all other territories over which the Philippines has sovereignty or jurisdiction, consisting of its terrestrial, fluvial and aerial domains, including its territorial sea, the seabed, the subsoil, the insular shelves, and other submarine areas." See Philippine Constitution of 1987 art. 1.

21 L. Bautista, The Philippine Treaty Limits and Territorial Waters Claim in International Law, 5 Soc. Scr. Diliman 107127 (2009), available at http://journals.upd.edu.ph/index.php/socialsciencediliman/article/viewFile/2046/1956 (last visited on Sept. 2, 2013).

22 V. Arches II, It belongs to China, Manila Standard Today, Apr. 28, 2012, available at http://www.chinadaily.com.cn/ 
since 1935 while China was exercising its sovereignty in an open manner, the Philippines had adopted no law that included the Huangyan Island into its territory. ${ }^{23}$

In brief, territorial limits defined by international treaties and its constitution are undoubtedly fundamental to the Philippines territory; and these treaties and domestic laws have demonstrated that the Philippines never owned the Huangyan Island before 1946 .

\section{Did China Exercise Effective Occupation and Jurisdiction before 1946?}

Max Huber developed territorial acquisition theory in the Palmas Case (1928), by ruling that:

According to the view that has prevailed at any rate since the $19^{\text {th }}$ century, an inchoate title of discovery must be completed within a reasonable period by the effective occupation of the region claimed to be discovered. ${ }^{24}$

With this new doctrine, the Philippines questioned the validity of China's effective occupation before 1946 and even China's territorial sovereignty. What is effective occupation? To what extent can effective occupation acquire or consolidate territorial sovereignty in this case?

In the Eastern Greenland case, ICJ adjudicated a claim to sovereignty based "merely upon continued display of authority." The Court stated that such a claim "involves two elements each of which must be shown to exist: the intention and will to act as sovereign, and some actual exercise or display of such authority." ${ }^{25}$ In other words, effective occupation is a State's "continuous and peaceful display of sovereignty over the Island" ${ }^{26}$ by exercising its powers such as treaty-making, legislation, jurisdiction, administration, and exploitation. 'Continuous' means "manifestations of territorial sovereignty without considerable gaps in principle," but sovereignty would not be necessarily "exercised in fact at every moment on every point of a territory." ${ }^{27}$ 'Peaceful' refers to "no contestation or other action

world/2012-05/09/content_15246764.htm (last visited on Oct. 6, 2013).

23 Until 2009, President Gloria Macapagal-Arroyo enacted the Philippine Baselines Law of 2009 (Republic Act 9522). The new law classified the Kalayaan Island Group and the Scarborough Shoal as a regime of islands under the Republic of the Philippines.

24 Island of Palmas (Neth. v. U.S.), Award, 1928 Perm. Ct. Arb. (PCA) 846 (Apr. 4).

25 Legal Status of Eastern Greenland (Den. v. Nor), Judgment, 1933 P.C.I.J. (ser. A/B) No. 53, at 45-46 (Apr. 5), available $a t$ http://www.icj-cij.org/pcij/serie_AB/AB_53/01_Groenland_Oriental_Arret.pdf (last visited on Oct. 28, 2013).

26 Supra note 24 , at 869 .

27 Id. at 840 
whatever or protest against the exercise of territorial rights. ${ }^{28}$ Therefore, whether a State's occupation is effective depends on the specific conditions of each case as follows: (1) if there have been two competing claims to the sovereignty, "the tribunal has had to decide which of the two is the stronger" 2 ; (2) if "the other State could not make out a superior claim," the tribunal will be "satisfied with very little in the way of the actual exercise of sovereign rights," and " $[\mathrm{t}]$ his is particularly true in the case of claims to sovereignty over areas in thinly populated or unsettled countries." 30

As to the Huangyan Island, China's exercise of its sovereignty with the intention to act as sovereign, although little, is an effective occupation. First, the Huangyan Island has special features such as its distance from mainland China and its constitution is just a few islets above water unfit for human habitation or military station. Thus, China's display of sovereignty did not necessarily need to be exercised "in fact at every moment on every point" of the island. This is an international legal principle that has been upheld by ICJ and international practice because no State will occupy actually every rock or islet in its territorial sea. Second, the Chinese government exercised and displayed its sovereignty over the Island in this period. In January 1935, the Map Verification Committee of China ${ }^{31}$ confirmed and published the 132 names in English and Chinese for Chinese islands and other insular features in the South China Sea, including the Huangyan Island (Scarborough Reef), on its first gazette. ${ }^{32}$ In April 1935, the Committee published the Map of Chinese Islands in the South China Sea (Figure 2) which also included the island in Chinese territory. Third, neither intention or claim, nor any corresponding proof of exercise of sovereignty over the Huangyan Island before 1946 was alleged by the Philippines. In the Palmas case, Huber ruled in favor of the Netherlands, stating that: "No act of occupation nor, except as to a recent period, any exercise of sovereignty at Palmas by Spain [in the period from 1700 to 1906] has been alleged." ${ }^{33}$ The Eastern Greenland case enunciates that "the absence of any claim to sovereignty by another Power" and the inaccessible character of the parts of the country can give one State "a valid claim

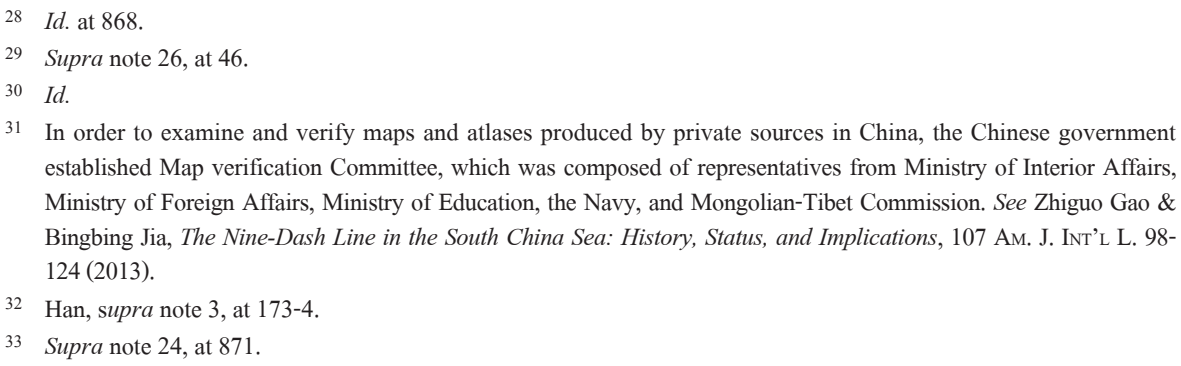


to sovereignty." ${ }^{34}$ The above discussion shows that China was exercising effective occupation compatible with the island's characteristics and under international law before 1946.

Figure 2: Map of Chinese islands in the South China Sea $(1935)^{35}$

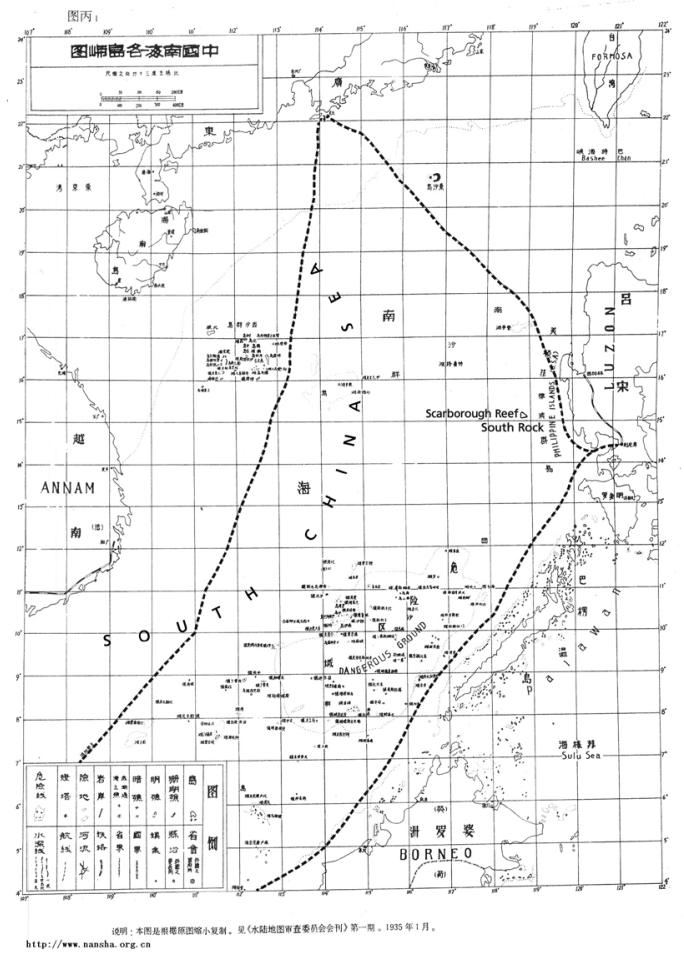

In Period I, China acquired its sovereignty over the Huangyan Island based on discovery and occupation, and has continuously consolidated it with the exercise of effective occupation and jurisdiction. On the contrary, there was no evidence which would establish the Philippines' display of sovereignty over the Island before 1946. The Philippines' territory has even been confined by the 'Treaty Limits' with accurate geographic coordinates, as recognized in its later domestic laws before 2009. Moreover, the Philippine Announcement of 2012 has not alleged that it had ever claimed its sovereignty over the Island before 1946. All of these could be "taken

34 Supra note 25 , at 50-51.

35 Map of Chinese Ilands in the South China Sea (1935) (modified by the author), available at http://www.nansha.org.cn/ islandsdatabase/4/South_China_Sea_Islands_Names.html (last visited on Sept. 2, 2013). 
to indicate the Philippine's acquiescence in its lack of ownership of the Huangyan Island," 36 and all these are an indirect proof of China's continuous and peaceful display of sovereignty.

\section{B. The Ownership in Period II: 1946 - 1997}

\section{Claims and Evidences from Both Parties}

The Philippine Announcement claims sovereignty on the basis of effective occupation and jurisdiction on the following grounds: flag-raising in 1965 and 1997; a map published in 1990; the Philippine navy's rehabilitation of a lighthouse in 1992; the use as an impact range by the Philippine and US Naval Forces; scientific, topographic and marine studies; and fishing grounds of Philippine fishermen. ${ }^{37}$

The Chinese Announcement, however, counter-claims that China continued exercising its sovereignty and exploitation of the Huangyan Island in this period, thus maintaining and consolidating its territorial sovereignty on the basis of the following evidence: designation by the government; official maps, announcements and proclamations; fishing grounds of Chinese fishermen; scientific expedition activities; and China's approval of international amateur radio expedition activities in 1994, 1995 and 1997 as noted below.

\section{Which of the Competing Claims is Superior?}

Both Parties alleged that they had exercised effective occupation and jurisdiction over the Huangyan Island, and proved their consistent position with various manifestations of sovereignty. Which of the competing claims is then superior?

First, the probative value accorded to maps as evidence of a display of sovereignty is given with caution. "International as well as national tribunals have in the past been reluctant to place much evidentiary value on maps." ${ }^{38}$ The international legal principles and practices have been consistent that, in determining the location of a boundary or territorial sovereignty, maps in general have no independent evidentiary value, especially private ones. International tribunals "treat maps warily if they are contradictory, self-serving, or of doubtful accuracy or provenance." 39 The map, cited in the Philippine Announcement, was published in 1990 by the US Coast and Geodetic Survey, who obviously had no intent to define the Philippines'

36 Gao \& Jia, supra note 31.

37 Supra note 9.

38 G. Weissberg, Maps as Evidence in International Boundary Disputes: A Reappraisal, 57 Am. J. INT'L L. $781-803$ (1963).

39 V. Prescott \& G. Triggs, International Frontiers and Boundaries: Law, Politics and Geography 214 (2008). 
territory. Moreover, it is contradictory with maps produced by the US Central Intelligence Agency in $1993^{40}$ and the Philippines Administrative Divisions Map of 1993 (Figure 3). Therefore, the map cited by the Philippines has little probative value in determining its territorial limits.

Figure 3 : Philippines Administrative Divisions Map of $1993^{41}$

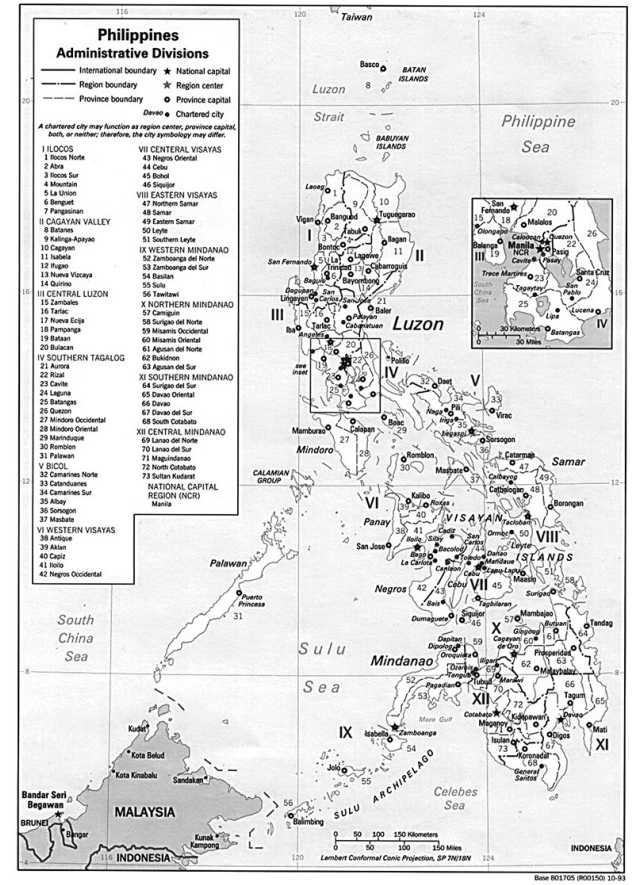

In contrast, both designations and map-publishing of the Island by the Chinese government are continuous and consistent. In 1947, the Chinese government announced, for the second time after 1935, the 172 names of islands in the South China Sea, in which Scarborough Shoal was included and renamed as Minzhu (Democratic) Reef (Figure 4) as a part of the Zhongsha Islands, and later published on newspapers by Department of Interior Affairs, together with the South China

40 Three maps of the Philippines had been produced by the US Central Intelligence Agency in 1993, none of which included the Huangyan Island into its territory. For details, see Perry-Castañeda Library Map Collection, The University of Texas at Austin, available at http:/www.lib.utexas.edu/maps/philippines.html (last visited on Sept. 2, 2013).

41 See US Library of Congress, Philippines Administrative Divisions, available at http://www.loc.gov/resource/g8061f. ct001416 (last visited on Sept. 21, 2013). 
Sea Islands Map (Figure 5). In 1983, the China Board on Geographic Names released "Geographic Names of Some of South China Sea Islands," in which the Huangyan Island became the standard name, with Democratic Reef as its alternative. All these maps, cited in the Chinese Announcement, were officially published by the Chinese governments (Figure 6) with an intention to determine its sovereign territory. ${ }^{42}$

Comparing with the private maps cited in the Philippine Announcement, these official maps cited in the Chinese Announcement are more advanced in mapmaking skills and accuracy, as well as more valuable for clarifying the intentions of the State. ${ }^{43}$ Hence, it may be safe to say that the probative value of these maps is superior to those of the Philippines'.

Figure 4: Comparison of Names of South China Sea Islands, released by Department of Interior Affairs in 1935 and $1947^{44}$

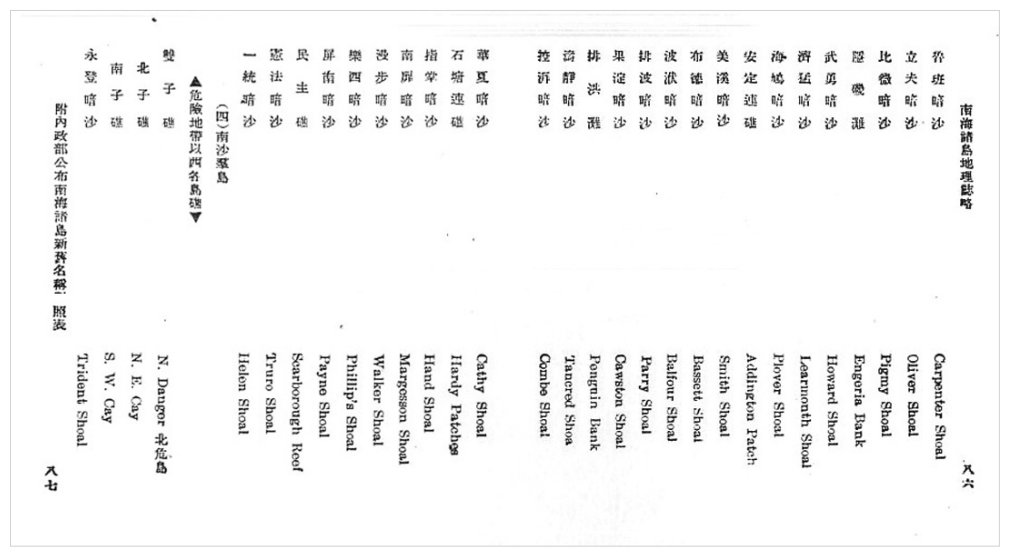

42 Id.

43 Ling-jie Kong, A Comparative Study of the Arguments of China and the Philippines on Sovereignty over Huangyan Island, 1 SoutheAst Asian Affairs 18-26 (2013), available at http://caod.oriprobe.com/articles/32140830/A Comparative_Study_of_the_Arguments_of_China_and_the_Philippines_on_S.htm (last visited on Sept. 21, 2013) .

44 See Comparison of Names of South China Sea Islands (1935 \& 1947), Nansha, available at http://www.nansha.org.cn/ islandsdatabase/4/1947_1935_South_China_Sea_Islands_Names_page3.jpg (last visited on Sept. 21, 2013). 
Figure 5: South China Sea Islands Map (1947)

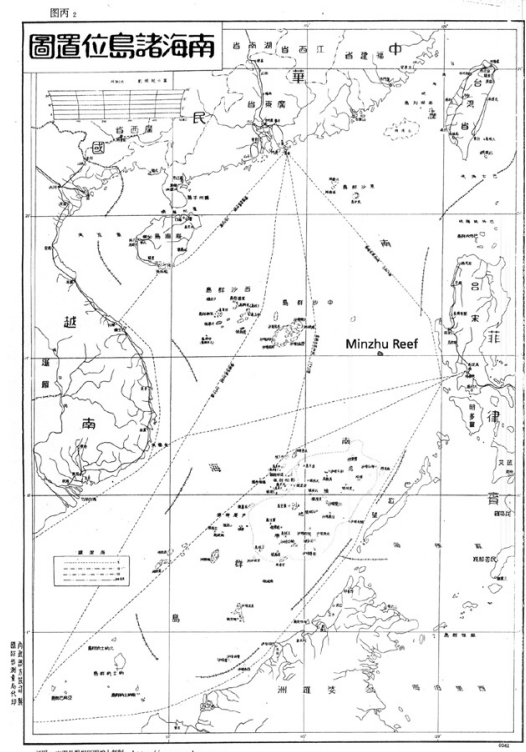

Figure 6: South China Sea Islands ${ }^{46}$

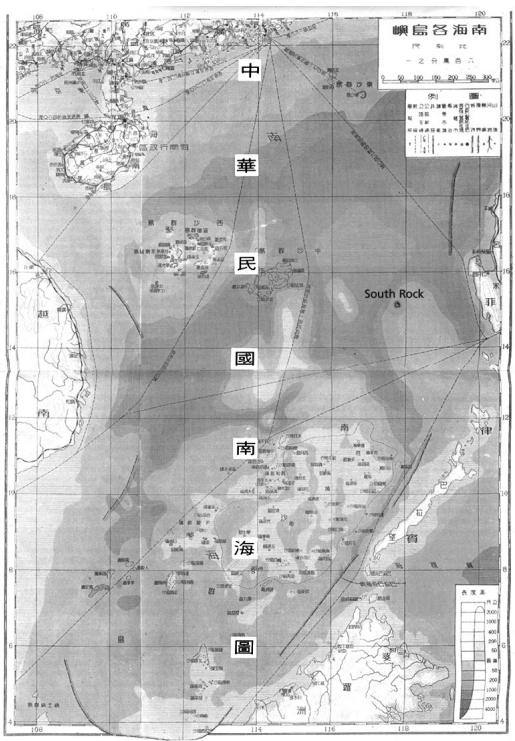

45 See South China Sea Islands Map (1947), Nansha(modified by the author), available at http://www.nansha.org.cn/ islandsdatabase/4/1947_South_China_Sea_Islands_Map.jpg (last visited on Sept. 21, 2013).

46 See South China Sea Islands Map (1946), published by the then Republic of China, Nansha(modified by the author),

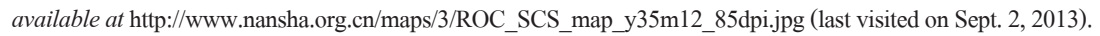


Second, a State's peaceful and continuous display of sovereignty with its flagraising, military utilization, etc., is one of the most important types of evidence in its territorial claim. However, the scarce and incidental symbolic occupation by the Philippines is not enough to prove its effective occupation and jurisdiction. On one hand, the flag-raising in 1965 was non-official, and the flag-raising in 1997 had been protested by China, in consequence becoming the landmark incident that crystalized the dispute. On the other hand, the US government never claimed sovereignty over any piece of land that the US and its allies used as an impact range, although it is illegal for the US Navy and the Philippines to put the Huangyan Island into military usage without China's permission. ${ }^{47}$ Thus, the evidence cited by the Philippine Announcement are not enough to prove its effective occupation and jurisdiction over the island.

In addition, China organized many scientific research activities at the Island and in its adjacent waters. It also approved expedition activities held by international amateur radio group in 1994, 1995 and 1997. In this sense, China's display of sovereignty is superior in diversity and probative value, but is not overwhelming the Philippines', or vice versa.

Third, in the Eastern Greenland case, ICJ stated: "Legislation is one of the most obvious forms of exercising sovereign power." ${ }^{\prime 8}$ Lawmaking has been regarded as the most critical evidence of the governmental position on territorial sovereignty. China continued to exercise its sovereignty over the Huangyan Island with numerous announcements, declarations and legislations pursuant to its sovereignty over the South China Sea islands, including Foreign Minister Zhou Enlai’s Statement on the US-British Draft Peace Treaty with Japan and the San Francisco Conference (1951) ${ }^{49}$ Declaration of the Government of the People's Republic of China on the Territorial Sea (1958), ${ }^{50}$ Decision of the Second Session of the Sixth National People's Congress on the Establishment of the Hainan Administrative Region (1984), ${ }^{51}$ Law of the People's Republic of China on the Territorial Sea and the Contiguous Zone (1992),52 and Statement Made after its Ratification of the United Nations Convention

47 Supra note 43.

48 Supra note 25 , at 48.

49 See A Chinese version of the Statement, available at http://news.xinhuanet.com/ziliao/2004-12/15/content_2337746. htm (last visited on Oct. 6, 2013).

50 See A Chinese version of the Declaration, available at http://law.people.com.cn/showdetail.action?id=2556477. Unofficial English version is available at http:/www.chinalawedu.com/news/23223/23228/24714.htm (all last visited on Oct. 6, 2013).

51 See A Chinese version of the Decision with unofficial English Translation, available at http://www.lawinfochina.com/ display.aspx?lib=law\&id=12915\&CGid= (last visited on Oct. 6, 2013).

52 See A Chinese version of the Law with unofficial English Translation, available at http://www.lawinfochina.com/ 
on the Law of the Sea (1996). ${ }^{53}$

However, the Philippine Announcement seems not consistent with the Philippine government's position. First, it is contrary to international treaties and domestic laws concluded in this period, such as The Philippines-US Treaty of General Relations of 1946, The Philippines-US Mutual Defense Treaty of 1952, Act to Define the Baselines of the Territorial Sea of the Philippines of 1961 (Republic Act No. 3046) and An Act to Amend Section I of Republic Act No. 3046 of 1968 (Republic Act No. 5446). Without exception they excluded the Huangyan Island from the Philippine territory under 'Treaty Limits,' as well as the basepoints and baseline of the territorial waters. ${ }^{54}$ Its governmental position was also reflected in the official maps (Figure 7) and publicized by the Philippine National Mapping and Resource Information Authority ("NAMRIA") in this period.

Figure 7: Official Map of the Philippines in $1990^{55}$

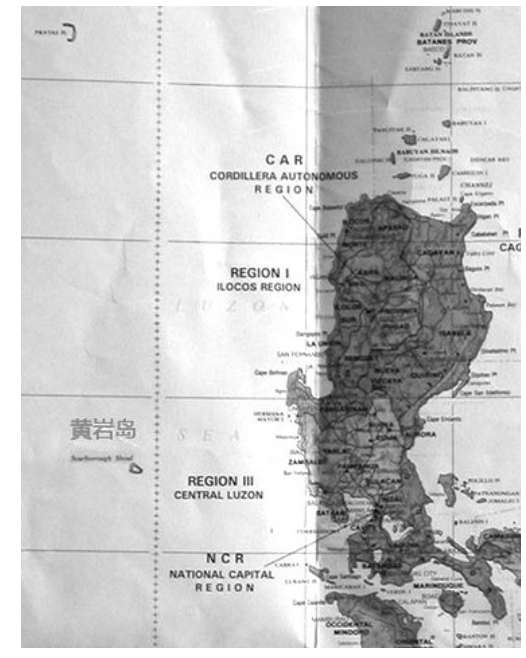

Second, the Philippines never challenged China's sovereignty and jurisdiction over the Huangyan Island during this period. Instead, it officially and explicitly

display.aspx $?$ lib=law\&id $=670 \&$ CGid $=($ Last visited on Oct. 6, 2013).

53 UN Division for Ocean Affairs and the Law of the Sea, Declarations and Statement, available at http://www.un.org/ depts/los/convention_agreements/convention_declarations.htm\#China Upon ratification (last visited on Oct. 6, 2013).

54 Supra note 43.

55 See Ten Questions Regarding the Huangyan Island, National Institute for South China Sea Studies(modified by the author), available at http://www.nanhai.org.cn/en/news_detail.asp?newsid=2547 (last visited on Sept. 2, 2013). It is showing that the Huangyan Island is lying outside the boundary of the Philippine territory. 
stated that the Island did not belong to the Philippines. E.g., the former Philippine Ambassador to Germany stated in his letter to German radio amateurs on February 5, 1990 that the Huangyan Island was not within the territory of the Philippines according to NAMRIA. ${ }^{56}$ Also, the document issued by NAMRIA on October 18, 1994 and the document from the Philippine Amateur Radio Association to the American Radio Relay League on November 18, 1994 confirmed that the territorial boundary and sovereignty of the Philippines were provided for in the 1898 Treaty of Paris with the Huangyan Island outside the Philippine territory. ${ }^{57}$

These legislations and official statements made by the Philippine authorities, together with its acquiescence to the China's exercising sovereignty over the Huangyan Island in this period, may have the legal effect of 'estoppel. ${ }^{58}$

In conclusion, the evidence cited in the Philippine Announcement is either private in nature or self-contradictory to its constitution, laws and governmental position, while the evidence cited in the Chinese Announcement reflected China's consistent position in its territorial claims. Therefore, the Chinese evidence, superior to that of the Philippines,' is sufficient to establish that China had exercised an open, continuous and peaceful effective occupation over the Huangyan Island in this period.

\section{Effective Occupation to Acquire the Huangyan Island?}

'Occupation' is "the appropriation by a State of a territory which is not at the time subject to the sovereignty of any State." ${ }^{\prime 59}$ In the Western Sahara case, ICJ opined that:

\footnotetext{
'Occupation' being legally an original means of peaceably acquiring sovereignty over territory otherwise than by cession or succession, it was a cardinal condition of a valid 'occupation' that the territory should be terra nullius - a territory belonging to none - at the time of the act alleged to constitute the 'occupation. ${ }^{60}$
}

However, "because the whole globe is now subject to some State's sovereignty", "occupation has become obsolete." ${ }^{61}$ China's discovery and occupation of the Huangyan Island in the $13^{\text {th }}$ century and the designation by the Spanish colonizers and their map published in 1808 (cited by the Philippines as evidence), have proved

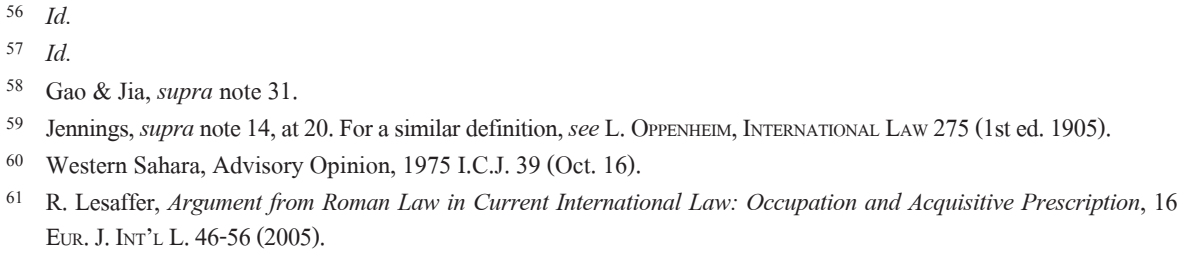


it was not terra nullius in 1946. So it is impossible for the Philippines to legally acquire the sovereignty of the island on the basis of occupation.

Then, 'prescription' would be the only possible "principle of public international law" on territorial acquisition, which could be claimed by the Philippines. ${ }^{62}$ By far, ICJ has never ruled on basis of acquisitive prescription. However, M. Huber seemed to have identified "continuous and peaceful display of State authority" with "prescription, ${ }^{13}$ which could be regarded as an embryonic definition of prescription. D. Johnson provided:

'Acquisitive prescription' is the means by which, under international law, legal recognition is given to the right of a state to exercise sovereignty over land or sea territory in cases where that state has, in fact, exercised its authority in a continuous, uninterrupted, and peaceful manner over the area concerned for a sufficient period of time, provided that all other interested and affected states ... have acquiesced in this exercise of authority. ${ }^{64}$

Three elements are essential to 'acquisitive prescription,' namely, (1) exercise of sovereignty in the territory in question; (2) continuous, open and notorious display of sovereignty over the territory for a long period of time; and (3) recognition or acquiescence from the other party. Therefore, "both a stricter proof of possession and a longer period of possession" ${ }^{65}$ are required to establish acquisitive prescription.

Can the evidence introduced by the Philippine Announcement satisfy the above tests? The answer will be 'negative.' The Philippines had made no claim over the Island's sovereignty before 1946, nor protested against China's exercise of sovereignty until 1997. These facts, and the international treaties, domestic laws, maps, and official statements, show that it never exercised sovereignty over the Huangyan Island. The activities, such as flag-raisings, military mobilization, scientific research or fishing, are either non-official (conducted by private persons), or non-peaceful (protested by China). It is thus impossible for the Philippines to anchor its claim of sovereignty to the Island on acquisitive prescription.

To sum up this period, China maintained and further consolidated its title through its effective occupation of the Island. Meanwhile, the Philippine Announcement is not only contradictory to its constitution and governmental position, but also inconsistent with international law on territorial acquisition.

62 Supra note 43.

63 Supra note 24 , at 868.

64 D. Johnson, Acquisitive Prescription in International Law, 27 BRIT. Y.B. INT'L L. 353-354 (1950).

65 Id. at 349 . 


\section{The Ownership in Period III: After 1997}

\section{Critical Date}

'Critical date' is a concept often used by ICJ in deciding territorial disputes. In the Sovereignty over Pulau Ligitan and Pulau Sipadan case, ICJ confirmed the year of 1969 as the critical date, because the Court decided: "The present dispute crystallized in 1969 ... the year in which the Parties asserted conflicting claims to Ligitan and Sipadan. ${ }^{66}$ ICJ took a similar approach in the dispute between Singapore and Malaysia: "It was on 14 February 1980, the time of Singapore's protest in response to Malaysia's publication of the 1979 map, that the dispute as to sovereignty over Pedra Branca/Pulau Batu Puteh crystallized. ${ }^{967}$ In Territorial and Maritime Dispute between Nicaragua and Honduras in the Caribbean Sea case, ICJ also ruled that: "It necessary to distinguish two different critical dates which are to be applied to two different circumstances, ${ }^{\prime 68}$ thus considering 2001 as the critical date for the island sovereignty since Nicaragua in its 2001 Memorial expressly reserved "the sovereign rights appurtenant to all the islets and rocks claimed by Nicaragua in the disputed area, ${ }^{\prime 69}$ and 1982 as the critical date for delimitation of the disputed maritime area, when "the existence of [a] traditionally accepted line ${ }^{\text {"70 }}$ was formally raised. As a consequence, the key to determining critical date is whether the dispute has crystallized, or, in other words, whether the Parties have officially put forward competing claims in an unequivocal manner over territorial sovereignty or maritime interests. ${ }^{71}$

When would be then the critical date if the Huangyan Island dispute is before ICJ? The Philippine Presidential Decree No. 1599 of June 11, 1978 claimed a 200 nm EEZ, which involves only the issue of maritime interests instead of territorial sovereignty. ${ }^{72}$ It was not until April 1997 that both Parties raised directly competing

66 Sovereignty over Pulau Ligitan and Pulau Sipadan (Indon. v. Malay.), Judgment, 2002 I.C.J. 642, ๆ 31 \& 682, ๆ 135 (Dec. 17), available at $\mathrm{http} / / / \mathrm{www} . i \mathrm{cj}$-cij.org/docket/files/102/7714.pdf (last visited on Oct. 28, 2013).

67 Sovereignty over Pedra Branca and Pulau Batu Puteh, Middle Rocks and South Ledge (Malay. v. Sing.), Judgment, 2008 I.C.J. 28, ๆๆ 33-34 (May 23), available at http://www.icj-cij.org/docket/files/130/14492.pdf (last visited on Oct. 28, 2013).

68 Territorial and Maritime Dispute between Nicaragua and Honduras in the Caribbean Sea (Nicar. v. Hond.), Judgment, 2007 I.C.J. 699, 123 (Oct. 8), available at http://www.icj-cij.org/docket/files/120/14075.pdf (last visited on Oct. 25, 2013)

69 Id. 129.

$70 \quad I d . \uparrow 131$.

71 Jianjun Gao, Comments on Philippine's Claim to Huangyan Island from Perspective of International Law (从国际法 角度评菲律宾对黄岩岛的主权主张) (available only in Chinese), 10 LEGAL SCIENCE MAGAZINE (法学杂志) 9-16 (2012).

72 See Presidential Decree No. 1599 (Jun. 11, 1978) claimed an EEZ up to $200 \mathrm{~nm}(370 \mathrm{~km})$ from the baselines from which their territorial sea is measured. See Presidential Decree No. 1599, Chan Robles Law Library (Jun. 11, 1978), available at $\mathrm{http}: / / \mathrm{www} . c h a n r o b l e s . c o m / p r e s i d e n t i a l d e c r e e s /$ presidentialdecreeno1599.html\#.UiaFtrK1uw0 (last visited 
claims. The Philippine navy began to monitor and harass the International Amateur Radio Expedition to the Huangyan Island (April 30 - May 3, 1997), organized by the Chinese Radio Sports Association, and then removed the Chinese stone marker reading "the Huangyan Island," installed by China on the South Rock in March 1990; Congressmen Roque Ablan and Jose Yap erected a Philippine flag on the Island on May 17; Philippine President Fidel Ramos said on May 21 that the Huangyan Island "is within the exclusive economic zone of the Philippines," and the Philippines had the right to exploit and develop its resources. ${ }^{73}$ Since then, the Philippine navy has begun to harass, detain, and even attack Chinese fishing boats and fishermen. ${ }^{74}$ These actions led to fresh protests from China on May 22, claiming that the island has been Chinese since ancient times and that the Philippine claim has violated international law. At the same time, China demanded that the Philippines value historic facts and international law, and respect China's territorial sovereignty. ${ }^{75}$ On June 5, 1997, Domingo L. Siazon, Jr., the Secretary of the Philippine Department of Foreign Affairs, delivered a statement in a public hearing of the Senate Foreign Relations and Defense Committee, saying that: "Scarborough Shoal is a new issue on overlapping claims between the Philippines and China. ${ }^{.76}$ Later in the same year, he claimed expressly that: "We maintain that the Scarborough Shoal is part of our territory ... the Philippines has exercised sovereignty and effective jurisdiction over Scarborough Shoal as well as over waters surrounding the shoal." ${ }^{\text {" }}$

It is not until this period of time that the Philippines made an open official claim over the territory of the Huangyan Island. The dispute became crystallized then.

on Sept. 21, 2013).

73 See Philippines Announce Negotiations with China over Disputed Island, AP News (May 22, 1997), available at http:// www.apnewsarchive.com/1997/Philippines-announce-negotiations-with-China-over-disputed-island/id-c44c1e69a3f4f ac479e2652785d8a325 (last visited on Sept. 21, 2013).

74 Since then, the Philippine navy has arrested Chinese fishing boats and fishermen on a regular basis, e.g., 21 fishermen and boat 62098 (May 20, 1997); 22 fishermen and boats $00372 \& 00472$ (Jan. 11, 1998); 29 fishermen and their boats 311 and 313 (Mar. 11, 1998); 21 fishermen and their boat 62098 (May 21, 1998). Since 1999, the Philippine navy has become more violent. On May 23, 1999, two Chinese fishing boats (Qionghai 03091 \& Qionghai 03082) were chased and bombarded by the Philippine navy, with the first boat sunk. On July 19, 1999, a Chinese fishing boat (Qionghai 03061) was sunk by the Philippine navy. In January 2000, six Chinese fishing boats (including Qionghai 01008 , Qionghai 02022 \& Qionghai 09097) were harassed and robbed by the Philippine navy. See Jiang Huai, The Philippine Encroached on China's Huangyan Island (available only in Chinese), 10 World AfF. 20-21 (2012)

75 Chinese Ministry of Foreign Affairs, China demands that the Philippines value historic facts and respect its territorial sovereignty (available only in Chinese), PEOPLE's DAILY, May 23, 1997, available at http://www.people.com.cn/GB/shi zheng/252/4157/4158/20010212/393762.html (last visited on Sept. 2, 2013).

76 Keyan Zou, Scarborough Reef: A New Flashpoint in Sino-Philippine Relations?, 7(2) IBRU Boundary AND SECURITY Bulletin 71-81 (1999), available at https://www.dur.ac.uk/ibru/publications/view/?id=149 (last visited on Oct. 28, 2013).

77 Id. 
Hence, April 30, 1997 should be the critical date for the dispute over the territory of the Huangyan Island.

\section{The Value of Critical Date}

The critical date is the "determining moment at which it might be inferred that the rights of the parties have crystallized so that acts after that date cannot alter the legal position. ${ }^{78}$ When the dispute achieved its critical date, "the respective claims of the Parties therefore [found] themselves 'legally neutralized', and that, for this reason, their subsequent statement or actions are not relevant to the present proceedings." ${ }^{\text {"79 }}$ Their claims became so clear at this moment that any subsequent attempts to bolster them would be inconsequential to the legal analysis. ${ }^{80}$ Therefore, acts after this date shall not be taken into consideration by international tribunals "unless such acts are a normal continuation of prior acts and are not undertaken for the purpose of improving the legal position of the Party which relies on them." ${ }^{81}$ That is to say, the value of critical date lies in distinguishing between those acts which should be considered in order to establish or ascertain sovereignty and those acts which should not.

As to the territorial dispute over the Huangyan Island, only those acts undertaken before April 30, 1997 should be given evidentiary value in proving its respective sovereignty claims; any acts taken by any Party after this date, e.g., the Philippine flag-raising in 1997 and its 2009 Archipelagic Baselines Act, have no probative force. Therefore, any acts, undertaken by either party after April 30 1997, cannot alter the ownership of the Huangyan Island. Based on this doctrine, a preliminary examination of evidence mentioned in both announcements reveals China has adduced more substantial evidence than the Philippines.

\section{Conclusion}

Both announcements of China and the Philippines are the official proclamations

78 Shaw, supra note $15,431$.

79 Supra note 66, at 679, 9128.

80 M. Byers, International LaW And the Arctic 13 (2013). 'Critical date' is defined as "the date after which the action of the parties can no longer affect the issue.” See G. Fitzmaurice, The Law and Procedure of the International Court of Justice 260 (1995); R. Jennings \& A. Watts, Oppenheim's International Law 711 (9th ed. 1992). See also supra note 66 , at $682, \uparrow 135$.

81 Supra note 66, at 682, 9135. 
made by their governments amid escalating tensions over the Huangyan Island. They represent the most authoritative statements of the respective claims and the corresponding factual and legal bases. Two important dates, July 4, 1946 and April 30, 1997, have compartmentalized the Island's history into the following three periods.

Before 1946, China had acquired its territorial title over the Huangyan Island by discovery of terra nullius, or at least an inchoate title, in Palmas' standard, with its discovery and occupation in the 13th century, which later had been consolidated into a full title with the historical consolidation process. Meanwhile, the Philippines had never claimed anything in this period that might compete with the manifestations of Chinese sovereignty. Instead, its treaties, constitutions and laws confirmed the Huangyan Island lies out of its territory.

The Philippine evidence between 1946 and 1997, such as maps, flag-raising, military utilization, and scientific research, are either private in nature, or contradictory to its domestic laws, governmental position, and international law on territorial acquisition, thus making its claims vulnerable. China further consolidated its territorial title with evidence, such as numerous official maps, various manifestations of sovereignty, legislations, and official announcements, which are superior to those produced by the Philippines. Therefore, China had sufficiently exercised an open, continuous and peaceful effective occupation over the Huangyan Island in this period.

On April 30, 1997 the Philippines made an open official claim over the territory of the Huangyan Island. It crystallized the dispute, so that day is tentatively determined to be the critical date. According to the ICJ's critical date doctrine, only those acts undertaken before April 30, 1997 can be adduced to prove the respective claims of territorial sovereignty; no acts undertaken by either Party after April 30 1997 can alter the sovereignty ownership. If China has acquired and consolidated the Island's territorial sovereignty before this critical date, China is entitled to hold territorial sovereignty over the Huangyan Island.

In early 2013, the Philippines requested the Arbitral Tribunal declare that the Island "are 'rocks' under Article 121 (3) of the Convention and which therefore generate entitlements only to a territorial Sea no broader than $12 \mathrm{~nm}$ ”; and required that China refrain from preventing Philippine vessels from exploiting the living resources in the adjacent waters. ${ }^{82}$ The Philippines has not requested the Tribunal to

82 Embassy of the Republic of the Philippines to the United States, Notification and Statement of Claim on Jan. 22, 2013, available at http://www.philippineembassy-usa.org/uploads/pdfs/embassy/2013/2013-0122-Notification\%20and\%20 Statement\%20of\%20Claim\%20on\%20West\%20Philippine\%20Sea.pdf (last visited on Sept. 3, 2013). 
determine the Island's ownership on the following grounds: First, the Philippines would obviously like to evade China's reservation to UNCLOS dispute settlement mechanisms. ${ }^{83}$ Second, the Philippines has recognized that: "The UNCLOS, after all, being the applicable law on the seas, cannot be utilized to resolve conflicting claims to islands. This aspect of the dispute will still be resolved on the basis of which claimant-state has the superior evidence of effective occupation." ${ }^{84}$ As discussed above, China's territorial sovereignty over the Huangyan Island is not totally based on the U-shaped Line in the South China Sea, but also on inter-temporal international law, which had endowed China an inchoate title with its discovery and effective occupation in the thirteenth century, and then a full title with its historical consolidation process of continuous and peaceful display of China's sovereignty. This means that even though the Philippines may succeed in having the area declared 'rocks,' China will still own the Huangyan Island, whether they are 'rocks' or not.

83 China has made reservation to the dispute settlement procedures, with respect to disputes concerning the interpretation or application of Articles 15, 74 and 83 relating to sea boundary delimitation, historic bays or titles, according to Article 298 of the UNCLOS. For details, see UN Division for Ocean Affairs and the Law of the Sea, China: Declaration made after ratification (Aug. 25, 2006), available at $\mathrm{http} / /$ www.un.org/depts/los/convention_agreements/convention_declarations.htm\#China (last visited on Sept. 2, 2013).

84 H. Roque, Understanding our UNCLOS Arbitral Submission, Philippine Daily InquiRer, Jan. 24, 2013, available at http://opinion.inquirer.net/45487/understanding-our-unclos-arbitral-submission (last visited on Sept. 2, 2013). 